\title{
Rite of Transition in Guy of Warwick and Bevis of Hampton: The Liminal Persona in Betwixt and Between
}

\author{
Onur Ekler
}

Erciyes University, Turkey

\begin{abstract}
This article aims to analyze the Self-quests of two transitional heroes from two great Anglo-Norman romances, Guy of Warwick, and Bevis of Hampton in terms of Gennep's notion of the phases of Ritede Passage and Turner's notion of liminal state. It attempts to trace the heroes' journeys in light of Gennep's and Turner's terminology. The main purposein doing this this is to show that both heroes in both romances act as bridges to fuse the cultural elements between Pre-conquest and Post-conquest England in order to make the way for the birth of a new Self at individual and national levels with regard to changing dynamics of the contemporary society. It also discusses how the birth of a new Self necessitates the metaphorical deaths of the transitional heroes in both romances. This article is outlined as the introduction of the romances and the general discussion of the heroes' Self quests in both romances in light of Gennep's and Turner's notions.
\end{abstract}

Keywords-romance, Self, voyage, hero, rite, identity.

ÖZ_Bu makale, iki önemli Anglo-Norman romansı olan, Guy of Warewick, ve Bevis of Hampton' daki iki geçiş dönemi kahramanının Self yolculuklarını Gennep'in rite of passage teorisindeki aşamalar kullanarak ve Turner'ın öne sürdüğ̈ liminal durum fikrini kullanarak incelemeyi amaçlar. Kahramanların yolculuğunu Gennep'in ve Turner'in terminolojisini kullanarak izini sürme girişiminde bulunur. Bunu yapmaktaki temel amaç, her iki romanstaki kahramanların, çă̆daş toplumun değişen dinamiklerine uyum sağlayabilecek ulusal ve bireysel düzeyde yeni bir Self anlayışı yaratmak için Fetih öncesi ve sonrası Ingiltere arasında kültürel elementleri bir ara getiren köprü görevi görmelerini göstermektedir. Bu çalışma, ayrica her iki romanstaki geçiş dönemi kahramanlarının bu yeni Self anlayışının doğuşu için metaforik olarak ölmeleri gerektiğini tartışır. Bu çalışma öncelikle her iki romansa genel olarak tanıtır ve daha sonrada her iki romanstaki kahramanlarin Self yolculuklarını Gennep ve Turner'ın teorileri ışı̆̆ında tartışır.
Anahtar Kelimeler: romans, Self, yolculuk, kahraman, ayin, kimlik

\section{INTRODUCTION}

"Rite de passage", that is, rite of transition as Gennep terms, helps order the crises, which one experiences in his life voyage and which necessitates one to shed his/her old Self with a new one with regard to the changing dynamics of the relevant time. He defines "rite de passage" as "rites, which accompany every change of place, state, social position. "By rites, he means three phases: separation, liminal state (margin), aggregation or incorporation. The first phase of separation signifies the hero's detachment from his earlier fixed state in the relevant socio-cultural dynamics. The second phase is the liminal state in which the ritual subject becomes a displaced passenger. In other words, in this state, the hero attempts to survive through the vortex of the existential angst in symbolical way. The hero is stuck in betwixt and between. As we will argue more in the following parts, the liminal stage in rites of passage is the stage of naked Self when the hero is secluded from his culturally imposed Self. The third phase of aggregation is the stage where the transformed Self is incorporated or reintegrated back into society. The third phase is not always achievable. The hero might be stuck in purgatory or chaos just as Victor W. Turner has claimed in his essay; Betwixt and Between: The Liminal Period in Rites De Passage. It is the state on which this study will attempt to put its focus since Destruction and creation of the Self occur at the same time in the hero's death in liminal state in order to pave the way for a new transformed society just as it happened in two important Anglo Norman romances, Guy of Warwick and Bevis de Haumton. Both romances have close resemblance in terms of having exile-return structure. Both romances capitalize on mythical and symbolical voyages in which the heroes, as the representatives of their societies are able to face off the haunting memories, anxieties of their existing societies. Within this frame, as mentioned above, both romances 
will be evaluated as transitional romances that pave the way for the making of a new society.

As will be detailed later, both Bevis and Guy separate from their culturally imposed selves in one way or another. They shed their selves in their voyages to distant lands. At that point, they stay on the way from being to Self-becoming. They are naked anymore in a liminal place. But their aggregation to newly established society seems not to be achievable since they are transitional selves.The initiation of the existing society into its newly created Self requires the physical or metaphorical death of the transitional selves, the heroes, who represent the society in this voyage.

This paper will be twofold. Itfirst aims to introduce briefly Guy of Warwick and BevisofHampton. Secondly it attempts to prove the aforementionedargument in this two romances showing the heroes' journeys in Arnold Van Gennep's ritual phases and how they are stuck in the liminal stage, between and betwixt.

\subsection{About Guy of Warwick and Bevis of Hampton}

Guy of Warwick and Bevis of Hamptonare regarded as two of most popular crusading romances since they were composed.Their popularity equally stand stretching beyond the boundaries thoughGuy of Warwickis much longer than Bevis de Haumton. Guy has almost 11000 lines while Bevis has over 4600 lines.However,there is still dispute over the exact dates of the original versions of both romances.As Wilcox has noted, both Guy of Warwick and Sir Bevis of Hamptonare considered having been composed in a time that marked the end of third crusade that corresponded to the end of $12^{\text {th }}$ centuryor the beginning of $13^{\text {th }}$ century. The translations of both romances into Middle English were around 1300 (29). As Wilcox has alsoargued, both romanceshave various Middle English versions and different manuscripts. The differences in versions and manuscripts might have resulted from their popularity as Cohen says:

\section{[...] Guy of Warwick and Sir Bevis of Haumton} continued to be copied, read, and enjoyed for several hundred years after they were first composed. Clearly, then, an argument that ties the cultural use and meaning of these narratives solely to theirmoment of genesis is inadequate. (91)

Though there is no consensus over the original date for composition, the settings of both romances evidence that they took place in pre-Norman Conquest. Guy was under the rule of King Athelstan (r. 924-939) and Beviswas under the rule of King Edgar (r. 959-975). It is noteworthy to say that both romances were functioned as a bridge to fuse the old and new values and thus helping the transient folk adapt to the new changing conditions. In this respect, both romances are quite of significance in that they both played crucial roles as Rouse defines, "for the construction of Englishness" (73). This is an idea also shared by Cohen, defining them as "identity romances" (90). Crane also proposes that Guy and Bevis' crusading voyages unto heathen lands have made slow but great contribution to the Self-making of English society (61).

\section{2- Rites of Transition in Guy of Warewick and Bevis of Hamptone: The Liminal Persona in Betwixt and Between}

Once meek, and in a perilous path,

The just man kept his course along

The vale of death.

Roses are planted where thorns grow.

And on the barren heath

Sing the honey bees (Keats, lines 3-8).

Rites of passage can be defined as a set of rituals whichsign the transition of a person through the life and death cycle, from one phase to another over time, from one position to another, integrating the man and social experiences with physical destiny. The physical and metaphorical interplay of life and death is at the heart of all rites of passage, and the battle between these two forcesalleges the vital paradox of our mortal side.

Victor W. Turner states that such rites are transitions between states. By "state" he means "a relatively fixed or stable condition" (234). like birth, initiation, marriage, pregnancy and giving birth, circumcision, entry into a profession, promotion into a higher social class, or death. And these rites help one shed his earlier state in favor of a new one. Turner defines transition as:

a process, a becoming and in the case of rites de passage even a transformation- here and apt analogy would be water in process of being heated to boiling point, or a pupa changing from grub to moth. (234)

As mentioned briefly in the intro of this study, Gennep in his seminal essay, The Rites of Passage, mentions three phases in rites of transitions. The first phase involves the hero's symbolic detachment from his earlier stable position or state. The second phase is the liminal period in which the hero is stripped from his existing identity and he is in between being and becoming. In this state, he turns into a transitional being 
or 'liminal persona'. He travels suspended in the paradox but celebrates it. In the third phase, the passage is consummated. In the last phase, the ritual subject is reintegrated back into society.

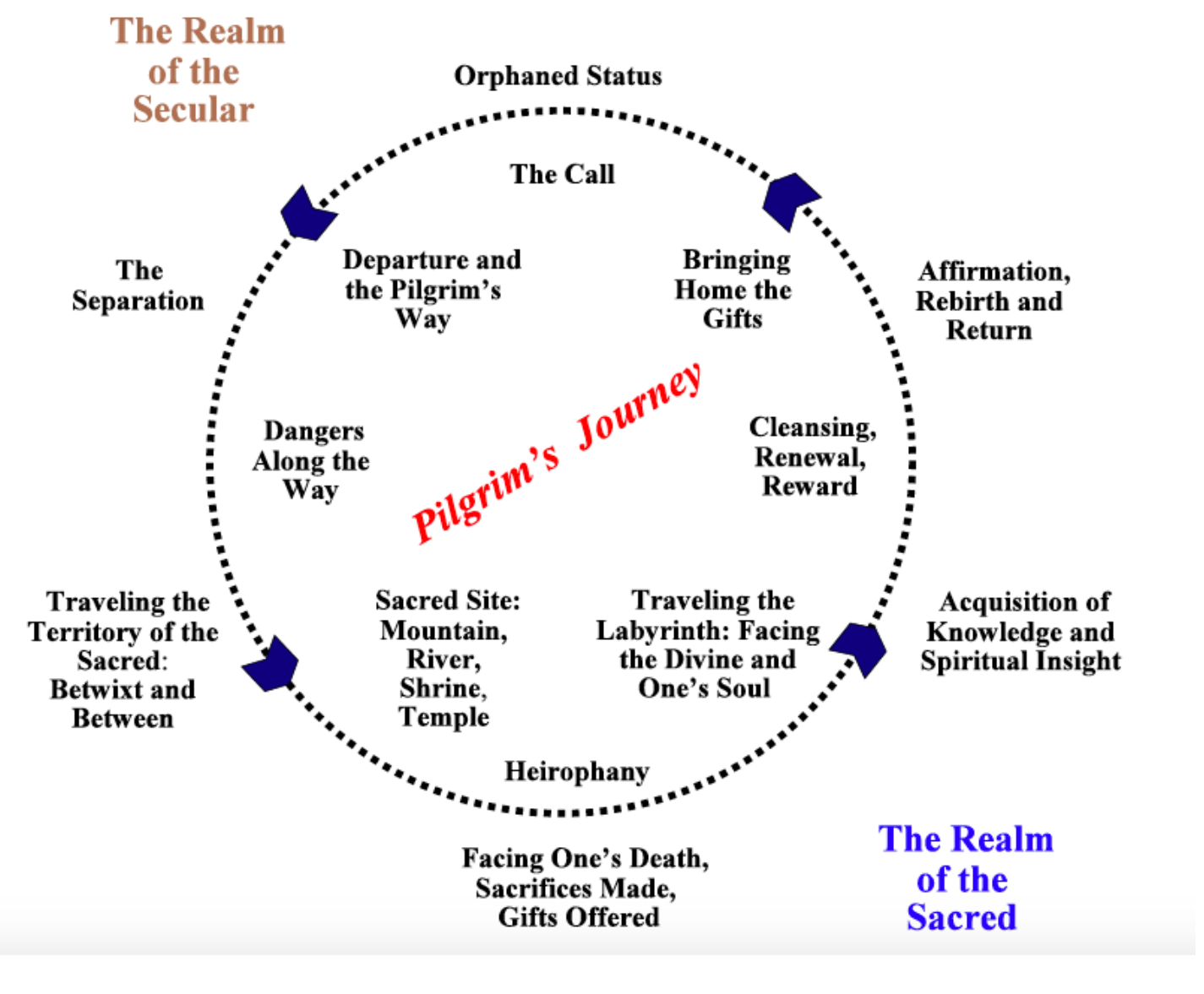

${ }^{1}$ http://www.webpages.uidaho.edu/\%7Erfrey/PDF/Shared/Pilgrimage\%20Diagram.pdf

As also argued in the introduction to this study, Sir Bevis of Hampton and Guy of Warwick have many common traits in many aspects of its focus. In the doubling technique of these two romances, Guy and Bevis move in a cyclic setting from England to the East and back again in terms of arrangement and consistency. In such episodic romances, it might be possible to see that Guy and Bevis' self-quests share some resemblances to Gennep's rite de passage. Both romances follow the structure of pilgrim's journey in rite of initiation. Both Bevis and Guy mark their separation by leaving England, which has constructed the constituents of their selves.

Guy's first separation occurs when he falls in love with his lord's daughter, Felice. A vassal's love for his lady is a well thought driving force for the ritual subject Guy to separate from his fixed state in order to win her heart. Felice does not show his love any interest unless he becomes a knight "- handsome, courteous and renowned, brave and bold, prized for his feats of arms (601-628)." But his real separation as a ritual subject occurs in the second part of the romance after his return from worldly voyage to England:

It was in May, in summertime, that Guy was in the city of Warwick... On a beautiful evening, Guy climbed a tower and leant out of the high gallery. He looked at the country round about and at the sky, which was so full of stars and at the clear and calm weather. Then Guy began to think how God had done him great honour; he had never done greater to any knight, for he was never in any place or fight that he was not considered the best. And he thought of how he was a man of influence and renowned in foreign lands and how he had killed so many men, captured towers and cities by force and had exerted himSelf far off in strange realms, for the sake of a woman whom he loved so much and for whom he had borne so much suffering- but never for his Creator, who had done him such 
great honour, nor had he bothered to serve him. But now he wanted to repent this. He began to sigh, and resolved in his heart that he would completely change his life and put himSelf at God's service. (Weiss 7563-94)

On the other hand, in Bevis of Hampton, separation occurs when Bevis's mother schemes the slaying of his father, and then attempts against Bevis' life when Bevisstruggles to claim his rightful throne by intending to kill his mother's lover:

"My fine lord emperor," said Bevis the wise, "you embrace my mother without my leave; you killed my father, whom I loved so much. Therefore, my lord, I ask you to return me my land, which you hold unlawfully and quite against my will." The emperor replied: "Silence, fool!" (Weiss, 297-302)

These are the moments when Both Guy and Bevis start to dissolve their imposed selves just as the elements do. Thomas Tymme's Practise of Chymicall Physiche, a famous book written on the transmutation of the elements in $17^{\text {th }}$ centurywell describes the dissolution and transmutation of elements as:

By transmutation I meane, when any thing so forgoeth his outward forme, and is so changed, that it is utterly unlike to his former substance and woonted forme, but hath put on another forme, and hath assumed another essence, another colour, another vertue, and another nature and property (qtd in Lichte, 91).

In their voyages to far off lands, the transformative phase, which is the liminal period begins. And in this phase, they become liminal personae. In this phase, with Turner's terms, they become the neophytes ${ }^{2}$, that is, they become neither dead nor living:

Transitional beings have nothing. They have no status, property, insignia, secular clothing, rank, kingship position, nothing to demarcate them structurally... In the words of King Lear they represent "naked unaccommodated man (Turner, 237)."

\footnotetext{
${ }^{2}$ According to V. W. Turner, The neophytes are likened to embryos newborn babies by symbolic means. The essential feature of this symbolization is that the neophytes are neither living nor death.
}

In this respect, Dr. Mary Douglas of University has called this process as pollution. She means by pollution as ritually unclean. Liminal personae pollute themselves and blur the boundaries. Both Guy and Bevis become structurally invisible and are commonly or partially detached from the culturally defined selves. This can be evidenced in many episodes in both Guy of Warewick and Bevisof Hampton. In one of the episodes in which Guy met his mentor Heralt whom he thought was killed in the fight against the men of Duke Otun, they don't know each other till they explain their identities:

As Guy was returning from hunting, he saw a poor man going in front of him. Then he called him over and gently asked him: "Worthy Sir, Where do you come from? Tell me, don't hide it from me!" "My Lord" he said from Lombardy where I led a very life: There I lost my Lord, a knight of very great valor. Duke Otun had us betrayed- may he never be forgiven for it I want to journey in this manner, always to pray for my Lord's soul." Guy said: "Who was your Lord, whom you loved with such great love?" He was called Guy of Warwick; there was no one more famous in the world." When Guy heard him give his name, he began to sigh. "Worthy man," he said, "tell me: upon your word, What is your name?" "In the kingdom where I was born I am called Heralt of Arderne (Weiss, 1553-76)."

They experience ambiguity, paradox and confusion. And this ambiguity manifests itself in the romances as Saracens, beasts, dragons, and giants.

In both romances, Saracens represent the lurking danger deep in one's psyche. East in both romances appears as a threatening place where the heathen, Saracens appear as the embodiments of the heroes' psychological fears before their Self-discovery. In the first part of the romanceGuy of Warewick, Guy defeats the Saracens who surround Constantinople; he also attracts the Byzantine Emperor's daughter and his empire. By defeating Saracens and declining Clarice's enticements, Guy shows himselfpraiseworthy of coming back to home and marrying Felice and getting her birthright of Warwick. In the second part, Guy as a ritual subjectmoves from chivalric knight to knight of God. When Guy turns out to be God's knight, his fight with the Saracens becomes deeply meaningful. The foe is depicted as physically, ethnically and now spiritually monstrous. Guy's first quest in the Holy Land happens when he meets Earl Jonas of Durras. He and his fifteen sons have been imprisoned. The King Triamour of Alexandria imprisons them.The King's irritating attitutes infuriates 
the Sultan.The Sultan tellsTriamour to find a warriorfor a single combat against, the huge, monstrousAmoraunt, a Saracen of Egypt. Triamour assigns Jonas with this mission.Heencounters Guy in disguise of a pilgrim. He tells the pilgrim (Guy) about his search for the great English warrior, Guy. Only after hearing Jonas' story of his captive sons, Guy consents to fight against Amoraunt to set them free from imprisonment. Guy's concealing his true identity is the sign of his symbolic dissolution of his existing identity and his transmutation into a palmer. Amoraunt here is one of the representatives of the paradox, ambiguity or confusion, which Guy has faced as a liminal persona. Guy as a liminal persona has to clean all these pollution in order to forge a new Self. And, he defeats the giant Amoraunt and sets Jonas and his sons free.In his return to England, he finds his homeland under invasion by Danish people. Danish king Anleaf brought a giant called Colebrant with him. Indeed, both Amoraunt and Colebraunt seem to be the same foe in representation. But the first represents his religious crisis and the latter does his national Self-crisis. Both symbolical monstrous figures can be seen as the obstacles to forge a new Self in individual and national awakening. After defeating his giant enemy, Colebraunt and setting England free from Danish invasion, he retreats into forest as a hermit in his last days. But his refusal to stay in Warewick and his preference to stay in forest symbolizes his identity crisis in between and betwixt. He has to die and dies in forest as an "unaccommodated man" in order to pave the way for a new born society. He is the one who represents society between past and present as a transitional Self. Out of his tomb, a new womb carrying a new society that breaks all the ties to past can be born.

On the other hand, in Bevis de Hampton,Bevis's confrontation with Saracens is different from Guy's. Bevis, sold to Saracen merchants at the age of seven, is taken to a heathen land governed by King Hermin. His liminal period as a ritual subject begins at an early age. His ultimate threat lies not in Saracen land but in his homeland, his cruel mother and his stepfather, German Emperor who kills his father and claims the throne. But still from the very beginning, the reader sees Saracens cannot be trusted. Even if he helps King Hermin defeat Bradmund, King of Damascus, King Hermin sends him to death by believing two knights' saying, "that wicked, manifest slave, Bevis of Hampton, has slept with your daughter... (Weiss, 765-94)" These two knights betrayed Bevis although he rescued them from Bradmund. In this episode;

"Bevis" said the King, "you must go to the King of Damascus, to carry this letter to Bradmund, your vassal, whom you defeated the other day, and you must swear to me by your faith that you will show the letter to no one except King Bradmund the warrior." (Weiss, 795-808)

This episode shows that he belongs to nowhere and $\mathrm{He}$ is as a liminal persona in between and betwixt.Bevis says in the face of this treachery: "I am most wickedly betrayed here. I believe I have not deserved his betraying me so badly: I conquered a kingdom for him with my sharp sword" (Weiss, 960-75). He becomes structurally invisible and strips of his former Self. Just as Felice does not know Guy as a poor pigrim when she serves food to poor pilgrims among whom Guy is there, in the episode where Bevis arrives in Monbrant and enters the palace, and he is dressed like as a palmer, Josiane does not know him weeping, "Dear Lord, in the name of God, where were you born?" (Weiss, 1362-1401) Bevis's former Self begins to dissolve and is in the process of transmutation into a new one.

Moreover, just as Guy encounters and defeats giants, Amoraunt and Colebraunt, Bevis encounters and defeats the giant, Escopart. Escopart here acts as a representation of ambiguity, paradox and confusion above all, pollution. His description as a Saracen evil signifies a crises Bevis as a liminal persona has to overcome:

A churl was certainly nine feet tall. In his hand he held a heavy club, which ten men could hardly carry, and by his side a good sharp sword. The space between his eyes was foot wide, his forehead was as large as an elephant's buttocks, his skin is blacker than ink, his nose was misshapen and knobbly in front, his legs too were long and thick and his feet long and flat. He was a hideous fellow...(Weiss, 1741-57)

And finally he wins the victory over Escopart and Escopart is converted into Christianity. One sees that monsters or giants are used to show the reader the distorted vision of the hero. This blurry vision is cleared out stage by stage until the hero strips of his imposed Self and becomes totally 'unaccomodated' or naked. In other words, monsters or giants enable the heroes to question his values, norms, and sentiments in the liminal period. Turner states:

Elements are withdrawn from their usual settings and combined with one another in a totally unique configuration, the monster and the dragon. Monsters startle neophytes into thinking about objects, persons, relationships and features of their environment they have hitherto taken for granted... The neophytes are divested of their previous habits of thought, feeling and action. 
During the liminal period, neophytes are alternately forced and encouraged to think about their society, their cosmos and the powers that generate and sustains them. (240)

Guy as a liminal persona fights two dragons, one near Constantinople, and the other is an Irish dragon ravaging Northumberland. Both of them are the shadows of his unconscious symbolizing his secular and religious crises. On the other hand, in Bevis of Hampton, Bevis's slaying the fierce boar in the forest and two lions devouring Bonefey the steward are the symbolical representations of his imposed Self. Like Guy,Bevishas to face his shadows in order to set his 'Self' free from restraints and forge a new identity. Like Guy, even if Bevis has a chance to restore his inheritance in the last episode, he leaves everything behind and travels with Josiane back to Monbrant where he lives in his remaining years. His disintegration and his travelling back to Monbrant rather than his incorporation to his earldom Hampton, is Bevis's metaphorical death. This metaphorical death is prerequisite for the renewal and rebirth of the society into a new transformed identity.

In brief, both Guy and Bevis as liminal personae are the transitional heroes who represent their societies in the liminal voyage.Both detach themselves from their imposed 'Self' and dissolve their 'selves' reducing them to nothing but naked and 'unaccommodated'. In that stage, they face their shadows in disguise of monsters, giants, or Saracens. Only when they overcome their shadows, both Guy and Bevis as liminal personae clear the blurry vision as ambiguity, confusion and paradox. At that moment, they notice they are not who they were anymore. So they renounce everything they have. And their metaphorical death happens. Out of their metaphorical deaths, new Englishness is forged.

\section{REFERENCES}

[1] Barron, W. R. J. English Medieval Romance. London and New York: Longman, 1987.

[2] Cohen, Of Giants: Sex, Monsters, and the Middle Ages (Minneapolis, MN: University of Minnesota Press, 1999

[3] Craft, Carolyn. "18: Romance." A Companion to Old and Middle English Literature. Ed. Laura Cooner Lambdin and Robert Thomas Lambdin. Westport, CT: Greenwood, 2002. 352-72.

[4] Crane, Susan. Insular Romance: Politics, Faith, and Culture in Anglo-Norman and Middle English Literature. Berkeley: University of California Press, 1986.
[5] Everett, Dorothy. Essays on Middle English Literature. Ed. Patricia Kean. Oxford: Clarendon, 1955.

[6] Fischer-Lichte, Erika. History of European Drama and Theatre, London: Routledge. 2001.

[7] Gennep, Arnold Van. Rites of Pasage. Chicago Press. 1960

[8] Kleinman, Scott. "The Exploitations of Medieval Romance." Philological Quarterly 91.1 (2012): 121

[9] Keats, John. The Marriage of Heaven Hell: The Argument Lines 3-8 retrived from http://www.bartleby.com/235/253.html on 08.01 .2015

[10]Loomis, Laura Hibbard. "Chaucer and the Auchinleck Ms: 'thopas' And' Guy of Warwick"' Essays and Studies in Honor of Carleton Brown. New York: New York UP ; H. Milford, Oxford UP, 1940. 111-48.

[11] Marti, Kevin. "10: Dream Vision." A Companion to Old and Middle English Literature. Ed. Laura Cooner Lambdin and Robert Thomas Lambdin. Westport, CT: Greenwood, 2002. 178-95.

[12] Matthews, David. "Whatever Happened to Your Heroes? Guy and Bevis after the Middle Ages." The Making of the Middle Ages: Liverpool Essays. Ed. Marios Costambeys, Andrew Hamer, and Martin Heale. Liverpool, England: U of Liverpool, 2007. 54-70.

[13] Rouse, Robert Allen. "An Exemplary Life: Guy of Warwick as Medieval Culture-Hero." Guy of Warwick: Icon and Ancestor. Eds. Alison Wiggins and Rosalind Field.

[14] Cambridge: D.S. Brewer, 2007. 94-109.

[15] Victor W, Turner. Sacred Realms Essays in Religion, Belief and Society - Oxford - Oxford University Press - 2004

[16] Weiss, Judith. Bevis de Haumtone and Gui de Warewick: Two Anglo Norman Romances. Ed. Telma Fenster and Jocelyn Wogen-Browne. Tempe,Arizona. 2008.

[17]Wilcox, Rebecca Anne. Cultures of conquest: romancing the East in medieval England and France. Diss. 2009. 